\title{
6
}

\section{Translating and Internalising International Human Rights Law: The Courts of Melanesia Confront Gendered Violence}

\author{
Jean G. Zorn \\ City University of New York School of Law
}

\section{Stories}

Discrimination against women takes many forms. In Fiji, a sister and her improvident brothers argued over the disposition of their dead father's estate. The brothers had already disposed of a good deal of it, in the worst ways possible, running a once prosperous sugar cane business into the ground and stripping a formerly thriving farm of all its top soil. The sister, afraid-and for good reason-that her brothers would fritter away what was left, asked the court to appoint her administrator of the estate in their place. But the laws of Fiji provided, in no uncertain terms, that the courts were to appoint sons, not daughters, to administer the estates of their deceased parents.

In Kiribati, a young woman was brutally raped. As with most rapes, however, no one was there to see it happen except the woman and her rapist. And he said she was lying. In most courts today-not just in the Pacific, but around the world - that would have all but put an end to the trial, because, in most countries, a rapist cannot be convicted on 
the uncorroborated testimony of his victim. A court is free to convict defendants charged with robbery or fraud or assault, even when there is no evidence beyond the word of the victim. But rape - that most private of crimes - is in many jurisdictions an exception.

And, in Vanuatu, a husband claimed in divorce proceedings that the businesses he had started during the marriage belonged to him alone, despite the fact that, throughout their marriage, she had taken full charge of their home and children, had worked herself, had paid for all the household expenses and had contributed to the businesses. Since the Vanuatu legislature had never invalidated the 19th-century British statutes governing the allocation of property in divorce, the court could well have given the businesses to him, leaving him wealthy and her with virtually nothing.

What do these three stories have in common? One point of similarity is obvious: all involve a woman subjugated, exploited or endangered. But that is not the whole story. Another common thread in their stories is that each of the women found herself in court and, in each case, despite local laws that discriminated against women and would have held against them, the court or legislature was able, using international human rights treaties and conventions, to fashion a new, liberating remedy.

\section{Introduction}

In 1979, when the Convention to Eliminate All Forms of Discrimination against Women (CEDAW) was adopted, it was a groundbreaking instrument, the first international treaty to recognise that women's rights are human rights. But that original version of CEDAW contained no mention of rape or domestic violence. It took another decade for gender violence to be included among the discriminatory laws, customs and actions that CEDAW outlaws.

The realisation that gender violence is a human rights issue, and that CEDAW requires states to take steps to end it, has had a positive impact on Melanesian women. It has energised women's groups and given them new tools and ideas to work with. Women in Papua New Guinea, fresh from attendance at world conferences on women in Copenhagen (1980) and Nairobi (1985), formed a coalition that produced books, pamphlets, posters, legislation and even a film promoting gender 
equality and calling for an end to gendered violence. A decade later, women in Vanuatu attended their first UN women's meeting (in Beijing, in 1995), and with a new appreciation of the world's willingness to help them, they actively, and ultimately successfully, campaigned for CEDAW to be ratified by Vanuatu. ${ }^{1}$

Despite those gains, however, women in Melanesian societies continue to occupy a subordinate status, and violence against women remains an intransigent problem. Politicians, journalists and scholars have given numerous reasons for CEDAW's less than absolute success. Two of the leading CEDAW scholars, Sally Engle Merry and Bonita Meyersfeld, come at their studies from differing, though overlapping, perspectives-Merry is a legal anthropologist; Meyersfeld is a specialist in international law-and arrive at differing, though not entirely different, conclusions: while both agree that CEDAW has to date hardly been implemented, they disagree about where the responsibility lies for its implementation, how it gets implemented, and therefore how effective it has been to date, and how likely it is to be effective in the future. ${ }^{2}$

Merry, in her 2006 study of the impact of CEDAW, saw a relative lack of progress in ending violence against women, despite the mobilisation of international organisations, and suggested that one reason for it is the disconnect between the rarefied corridors of the United Nations headquarters in New York and Geneva and the variable, variegated, ever-changing local cultures that CEDAW is supposed to affect. ${ }^{3}$ Merry posits that the legal culture of international human rights workers is so different from the cultures of women's groups and other local organisations within nation-states that they misunderstand and often talk past one another. ${ }^{4}$

1 Jean Zorn, 2003, 'Custom then and now: The changing Melanesian family', in Passage of Change: Law, Society and Governance in the Pacific, ed. Anita Jowitt and Tess Newton Cain, pp. 95-124, Canberra: Pandanus Books.

2 The results vary from country to country, from researcher to researcher, and depend on what each study denotes as indicia of changing norms. Merry finds less than total acceptance of CEDAW's goals in Fiji and India. See Sally Engle Merry, 2006, Human Rights and Gender Violence: Translating International Law into Local Justice, Chicago: University of Chicago Press, pp. 103-33. Meyersfeld finds significant changes, in the direction of making domestic violence a higher profile state concern, in Sweden, Nicaragua and Mexico. See Bonita Meyersfeld, 2012, Domestic Violence and International Law, Oxford: Hart Publishing, pp. 291-316.

3 Merry, Human Rights and Gender Violence, p. 1.

4 Ibid., p. 103. 
Meyersfeld's perspective is more traditionally legal. She describes CEDAW, like other examples of international law, as operating primarily on states (on national governments), not on individuals or groups within state boundaries. Finding many examples of changed state behaviour - that is, of governmental initiatives such as the addition to national criminal codes of domestic violence as a crime, the creation of governmental panels and commissions to study and find ways of combatting domestic violence, and the use by courts of CEDAW as a source of judicial decision-making - she pronounces CEDAW a qualified success. ${ }^{5}$

Their disparate perspectives are important to an understanding of how CEDAW might succeed in the Pacific. Merry describes two failures of vision that have hindered the Committee's attempts to change domestic laws and customs: first, the failure of both CEDAW's supporters and its detractors to understand the flexible and changing nature of the customs or culture of the reporting countries; and, second, the failure to understand that the world of international human rights experts is itself a culture, with its own beliefs, values and blind spots - a world that needs to be translated if it is to have an impact on the other world of domestic law and lifestyles.

Merry believes that CEDAW could be employed more effectively if the experts on the CEDAW Committee and other international actors took into account the ever-changing nature of custom in making their recommendations. With sufficient time and resources to make a thorough study of each reporting country's situation, the Committee could make recommendations that were more tailored to local circumstances, recommendations that would make use of local customs, circumstances and politics in effecting change. Culture and custom can become, in Merry's words, a resource for, rather than a barrier to, change. ${ }^{6}$

5 Meyersfeld, Domestic Violence and International Law.

6 Merry, Human Rights and Gender Violence, p. 9. To be fair to the international human rights workers, their essentialist view of culture and custom is also held by their opposition, conservatives within reporting states who wish to retain the status quo, despite or because of its subordination of women. They, too, reify custom, declaring that the UN's attempts to impose supposedly universal values will serve only to destroy local cultures. 
Merry's second point is that, despite the assumption of the international elites that culture is something that exists only in insular and isolated places, the meetings and reports and discussions, most of which take place in far-off capitals like New York or Geneva, of NGOs and other groups that make up the international human rights community, is itself a culture, with customs and values of its own:

Culture defined only as tradition or as national essence implies that villages are full of culture but that there is no culture in the conference halls of New York and Geneva. Yet, culture is as important in shaping human rights conferences as it is in structuring village mortuary rituals ... UN meetings are deeply shaped by a culture of transnational modernity, one that specifies procedures for collaborative decisionmaking, concepts of global social justice, and definitions of gender roles. Human rights law is itself primarily a cultural system. ${ }^{7}$

The particular culture of the international human rights world is centred not just on a firm conviction about the universal value of human rights, but also on a shared belief in the rule of law: 'The [CEDAW and other human rights] experts are applying the law. They are acting as a legal body to enforce compliance with the terms of a treaty ratified by the country. The human rights system is a legal system committed to the universal application of a code of conduct to myriad particular situations. ${ }^{8}$ This is a culture that drafts, lobbies for and attempts to enforce written laws. The enforcement mechanisms available to the CEDAW Committee differ from those that a judge in a state court can wield. Judges hand down verdicts, mete out sentences; except for the parties' right to appeal, their word is, well, law. Conversely, 'The impact of human rights law is a matter of persuasion rather than force, of cultural transformation rather than coercive change'.$^{9}$ Still, the two cultures have much in common. The experts on the CEDAW Committee share with judges in state courts a value system characterised by a deeply held belief that reason ought to trump bias, anger and other emotions and that the best and safest norms are those that are uniformly, impartially and universally applied. 
Merry's insistence that it is the task of the CEDAW Committee to come to a better understanding of the variations in local culture overlooks the basic truth that the achievement of CEDAW's aim of overcoming discrimination might be best served by ignoring the differences in local cultures and focusing on the ways in which all can meet this goal. Further, she places the major responsibility for carrying out CEDAW's requirements on non-governmental organisations, and perhaps social agencies within government, overlooking the role that other actors, particularly actors within national governmental and legal institutions - and, most particularly, legislators in parliament and judges in national courts - can play in translating CEDAW's principles for national consumption. Meyersfeld offers a beneficial corrective and addendum to Merry's study in viewing CEDAW as a law, not as a rallying cry, and in recognising that CEDAW is at its most effective in legal settings.

Merry focuses on legal cultures; Meyersfeld on legal institutions, pointing out that there are two ways in which international law can improve states' responses to domestic violence. First (as Merry also notes), international law has an expressive value: it stipulates norms, which define the contents of rights, and concomitant state obligations. The second function of international law (and here is where Meyersfeld's theory diverges from Merry's) is its implementing capability. International laws act on states, urging them to modify their laws in accordance with international standards. ${ }^{10}$

Meyersfeld posits, first, that international law is a legal structure, which regulates state behaviour', not individual behaviour. ${ }^{11}$ Even when an international covenant, such as CEDAW, purports to regulate the affairs of individuals within states, it is not actually addressing those individuals; it is telling the state to address those individuals. Its aim is to change the behaviour of states, and only through that, to reach the behaviour of individuals. Thus, CEDAW does not say that individuals should stop engaging in gender discrimination; it says that states should prohibit individuals from engaging in it.

10 Meyersfeld, Domestic Violence and International Law, p. xxxiv.

11 Ibid., p. 254. 
Meyersfeld's second premise is that, by its very nature, international law can have no enforcement mechanisms. Short of war, sovereign states do not enforce the law on one another; they act by agreement. Meyersfeld's third premise follows closely on the heels of her second: 'Despite the absence of an international legislature, judiciary or policing institution ... international law remains effective. The fact that it is not obeyed some of the time, does not mean that it is never obeyed at any time. ${ }^{\prime 2}$ To explain how international law is effective, Meyersfeld borrows from Harold Hongju Koh and others the theory of 'infiltration': 'Its method of enforcement ... is by infiltrating ... international norms through national courts, legal systems and political lobbying. ${ }^{13}$ The interactive process by which international law infiltrates national law and becomes 'internalized into a nation's domestic legal system' is the work of all the agencies of government, especially of the courts, which, by (interacting with CEDAW), then interpreting CEDAW's doctrines, gives them a domestic meaning, so that they can be 'integrated into national law and assume the status of internally binding domestic legal obligations'. ${ }^{14}$ Legislators and judges are the most able, and most likely, to be able to translate CEDAW into local practice, because they are themselves members both of the legal culture and, at the same time, of the local culture. Moreover, that is their job.

In this chapter I examine the many ways that lawyers and judges in Melanesian courts quite consciously and purposely go about the job that Merry describes as transplantation and translation and Meyersfeld describes as infiltration and implementation. I begin by describing CEDAW, what it provides, and how it is enforced, and then analyse a number of recent cases in which judges have discussed and even used CEDAW. ${ }^{15}$

\footnotetext{
12 Ibid.

13 Ibid., p. 256; see also Harold Hongju Koh, 1997, 'Why do nations obey international law?' Yale Law Journal 106: 2599-611; and the chapters in S. McDougal Myres, Harold D. Lasswell and Lung-chu Chen (eds), 1977, Human Rights and the World Public Order: The Basic Policies of an International Law of Human Dignity, New Haven: Yale University Press.

14 Koh, 'Why do nations obey international law?' p. 626, quoted in Meyersfeld, Domestic Violence and International Law, p. 258.

15 The list of databases can be accessed on the website of the Pacific Islands Legal Information Institute. All cases discussed in this article can be accessed there.
} 
As there have been too few cases in Melanesian courts using CEDAW to make a meaningful sample, I have extended my net to include cases from many of the Pacific Islands nations represented in the database of the Pacific Islands Legal Information Institute. The Pacific Islands Legal Information Institute's database of statutes and cases includes all the Anglophonic postcolonial nations of the Pacific, as well as NouvelleCalédonie. It does not include Australia, New Zealand, Hawai'i, or the Pacific Rim nations. I have limited my search to Anglophonic nations that were British, New Zealand and Australian colonies, territories and protectorates. Although there are many social, political and cultural differences among the Pacific Islands nations, there are also, I believe, enough continuities to make the study meaningful. Equally important, any Pacific Islands judge, finding insufficient precedents amongst the cases from his or her own jurisdiction, would be welladvised to look for analogies in decisions of the courts of other Pacific Islands states rather than such inapposite jurisdictions as Australia or England. Indeed, the Papua New Guinea Constitution, as well as the PNG Underlying Law Act, expressly recommend this course, as do the laws of other Pacific Islands jurisdictions. ${ }^{16}$

\section{CEDAW: Gender violence as a violation of human rights under international law}

Starting in the 1970s, and impelled, in large part, by women's NGOs, the member states of the United Nations began to recognise that women needed and deserved the protection and support of international law. A major consequence of this was the promulgation by the UN General

16 Papua New Guinea Consolidated Legislation.

If in any particular matter before a court there appears to be no rule of law that is applicable and appropriate to the circumstances of the country, it is the duty of the National Judicial System, and in particular of the Supreme Court and the National Court, to formulate an appropriate rule as part of the underlying law having regard (c) to analogies to be drawn from relevant statutes and custom; and (d) to the legislation of, and to relevant decisions of the courts of, any country that in the opinion of the court has a legal system similar to that of Papua New Guinea. 
Assembly in 1979 of the Convention on the Elimination of All Form of Discrimination against Women (CEDAW). ${ }^{17}$ CEDAW defines discrimination against women as:

Any distinction, exclusion or restriction made on the basis of sex which has the effect or purpose of impairing or nullifying the recognition, enjoyment or exercise by women, irrespective of their marital status, on a basis of equality of men and women, of human rights and fundamental freedoms in the political, economic, social, cultural, civil or any other field. ${ }^{18}$

CEDAW marks a radical change from 20th-century international law orthodoxy in a number of ways: first, by being among the first to include gender violence in its definition of human rights violations. But, when CEDAW was first promulgated, gender violence was not expressly included in it, and for almost a decade there was no certainty that it would be. CEDAW came into being in 1979 and, though women's groups and sympathetic NGOs had foregrounded gender violence by then, it was not until the late 1980s, after a great deal of work and effort, that there was sufficient consensus within the United Nations in support of the idea that gender violence was also a form of discrimination against women, deserving of international law protection, to guarantee its addition to CEDAW. The General Assembly issued two non-binding Resolutions declaring freedom from gender violence a human right, one in 1985, the second in $1990 .{ }^{19}$ The UN Committee created to interpret and enforce CEDAW, the Committee on the Elimination of Discrimination against Women (the 'Committee'), announced in 1989 that it would treat gender violence as a form of discrimination outlawed by CEDAW. By 1992, the Committee had promulgated General Recommendation No. 19, which corrected for the absence of an express CEDAW provision about gender violence by stating, 'the definition of discrimination includes gender-based

\footnotetext{
17 CEDAW was adopted by the United Nations General Assembly on 18 December 1979, opened for signature by the member nations of the UN on 1 March 1980, and came into force on 3 September 1981, 30 days after ratification by the requisite 20 nations. See Convention on the Elimination of All Forms of Discrimination against Women, G.A. Res. 34/180, U.N. GAOR, 34th Sess. Suppl. No. 46, at 193, U.N. Doc. A/34/46 (1979).

18 CEDAW, Article 2.

19 The 1985 UN Resolution (n 76) Art. 2 provides that states should take specific action urgently in order to prevent domestic violence and to render the appropriate assistance to the victims thereof'. See also 1990 Resolution (n 85).
} 
violence'. ${ }^{20}$ General Recommendation 19 defines 'gender-based violence' as 'violence that is directed against a woman because she is a woman or that affects women disproportionately ${ }^{\prime 21}$

The recognition of discrimination against women in general, and of gender violence in particular, as human rights violations are not the only ways in which CEDAW significantly enlarged the scope of international law. Traditionally, international law consisted of normative agreements between states, concerning the actions of those states towards one another and towards each other's citizens. Only in the 20th century, in such multilateral agreements as the Geneva Convention on Human Rights, did the scope of international law enlarge to include the relations of states towards their own citizens. CEDAW goes a step further. In calling for an end to discrimination and violence by individuals against one another, CEDAW is the first international law to concern itself with the actions of citizens within a state towards other citizens of the same state. ${ }^{22}$ But CEDAW cannot reach inside a state to hold the individuals who disobey it personally responsible; the most that CEDAW, like any other international law, can do is to hold the state responsible for the acts of its citizens. Nevertheless, the very fact that CEDAW does do that is a change to international law of paradigmatic proportions.

Predictably, from its beginnings CEDAW has stirred strong reactionsboth in opposition and in support. CEDAW provides that equal treatment for women should prevail not only over state laws and individual actions, but also over custom, and some of its strongest opposition has come from those who argue that, in questioning custom, CEDAW is yet another example of the West enforcing its own morality on other cultures, and consequently trampling on the

20 Meyersfeld, Domestic Violence and International Law, p. 34.

21 Committee on the Elimination of Discrimination Against Women, General Recommendation No. 19, 11th Sess., Agenda Item 7, U.N. Doc. CEDAW/C/1992/L.1/Add. 15 (1992). In 1995, the General Assembly passed the Declaration on the Elimination of Violence against Women. Although it is a persuasive statement in support of General Recommendation No. 19, it is, as the title 'Declaration' suggests, not binding.

22 It is, of course, not always true that individuals, and not states, are the perpetrators of gender violence. The international community has recognised that rape and other forms of violence against women are sometimes overt elements of state policy, particularly during wartime. As such, they are among the crimes punishable by the International Criminal Court. See Cour Pénal Internationale / International Criminal Court, 13 November 2011. 
sensibilities of third world nations. ${ }^{23}$ CEDAW's critics are correct in saying that CEDAW takes direct issue with custom. Articles 2 and 5 are key provisions for the nations of the Pacific, because they expressly obligate states to end customary norms and practices that involve gender discrimination. Under Article 5(a), ratifying states agree 'to take all appropriate measures' 'to modify the social and cultural patterns of conduct of men and women, with a view to achieving the elimination of prejudices and customary and all other practices which are based on the idea of the inferiority or the superiority of either of the sexes or on stereotyped roles of men and women'. Article 2(f) is aimed even more directly at abolishing discriminatory customs; it requires states 'to take all appropriate measures, including legislation, to modify or abolish existing laws, regulations, customs and practices which constitute discrimination against women'. And, at section 23(e), Recommendation No. 19, which added gender violence to the discriminatory acts CEDAW outlaws, CEDAW explicitly includes custom in the list of major causes of gender violence and proposes that states act to change or abolish these customs: 'States parties in their reports should identify the nature and extent of attitudes, customs and practices that perpetuate violence against women and the kinds of violence that result. They should report on the measures that they have undertaken to overcome violence and the effect of those measures. ${ }^{24}$

CEDAW and other international women's human rights laws, covenants and treaties have had considerable effect worldwide. It would be difficult to find any prominent institution or agency, within or without government, in any country today that is not aware of CEDAW and the standards it sets. But violence against women continues to be endemic

23 Jean Zorn, 1999. “'Women's rights are human rights": International law and the culture of domestic violence', in To Have and To Hit: Cultural Perspectives on Wife Beating (2nd edition), ed. Dorothy Counts, Judith Brown and J. Campbell, pp. 286-302, Urbana and Chicago: University of Illinois Press.

24 Convention on the Elimination of All Forms of Discrimination against Women: General recommendations made by the Committee on the Elimination of Discrimination against Women, n.d., UN Women. 
to most cultures, not least in the countries that make up Melanesia. Anthropologists, feminists and international law scholars have all put forward theories and speculations about why this might be so. ${ }^{25}$

One answer is that, because of the peculiar nature of international law, CEDAW's effectiveness is limited. First, because it is an international convention, a form of treaty, it applies only to those states that have ratified it. ${ }^{26}$ And, making CEDAW's reach even more limited, a number of the ratifying states have done so with reservations, by which they opt out of certain provisions, sometimes even including key requirements, like the state's promise to abolish customs or laws that promote gender discrimination. ${ }^{27}$ However, although it looked, for a while, as if this would be a major obstacle in the Pacific, CEDAW has now been ratified, without reservation, by every Pacific Islands nation except Tonga and Palau. ${ }^{28}$

But, even those states that have ratified CEDAW have few duties under it. CEDAW contains neither penalties for states that fail to follow it, nor enforcement methods to make them do it. The most that CEDAW actually requires of the signatory states is that they report every four years to the Committee about the extent of the state's compliance,

25 See especially the articles collected in Counts, Brown and Campbell (eds), To Have and To Hit: Cultural Perspectives on Wife Beating; Sinclair Dinnen and Allison Ley (eds), 2000, Reflections on Violence in Melanesia, Annandale NSW/Canberra: Hawkins Press/Asia Pacific Press; and Margaret Jolly, Christine Stewart and Carolyn Brewer (eds), 2012, Engendering Violence in Papua New Guinea, Canberra: ANU E Press.

26 For a list of all the countries that have ratified CEDAW, together with the dates of ratification, see United Nations Treaty Collection. For information about country reports to CEDAW, see Office of the United Nations High Commission for Human Rights.

27 A list of signatory, acceding and ratifying nations, including notes about reservations made by them, may be found at the United Nations Treaty Collection.

28 By 1991, only two Pacific island nations - Cook Islands and Niue - had signed, and they only because New Zealand, which was, at the time, responsible for their foreign affairs, had done it for them. Throughout the 1990s, however, propelled by the South Pacific Forum's support for the Convention, most of the rest of the nations of the Pacific signed on: Samoa in 1992; Papua New Guinea, Fiji and Vanuatu in 1995; Tuvalu in 1999. They were followed, in the next decade, by Solomon Islands in 2002, Kiribati and Federated States of Micronesia in 2004, and the Marshall Islands in 2006. The State of Palestine is, as of this writing, the most recent signatory, having been permitted to accede to the Convention in June of 2014, leaving only Tonga and Palau as Pacific nations that have not ratified CEDAW. Palau signed CEDAW on 20 September 2011, but has not ratified it, which means Palau is not bound by it. Tonga has neither signed nor ratified. The only other nations that have not yet ratified CEDAW are the Vatican, Iran, Somalia, Sudan, South Sudan and the United States. Even ratification may not be enough; governments are permitted to ratify with reservations and, of the Pacific island countries that ratified CEDAW, Cook Islands originally reserved in part as to Articles 2(f) and 5(a). Fiji originally reserved as to Articles 5(a) and 9. Both, however, have since withdrawn their reservations. 
if any, with CEDAW's aims. ${ }^{29}$ And there is no penalty if a ratifying state fails to report. ${ }^{30}$ Indeed, Papua New Guinea, which ratified CEDAW in 1995, did not draft its first report until 2008, and did not present it to the CEDAW Committee until 2010. That report, prepared under the direction of Dame Carol Kidu, who was at the time Papua New Guinea's Minister for Community Development, was titled Papua New Guinea's 'combined first, second, third and fourth reports'. Fiji, similarly, ratified the convention in 1995, but has filed just two reports: the first one, dated 2000, was brought up for discussion by the Committee in 2002; and the second report (which was titled a combined second, third and fourth report) is dated November 2008, and was discussed by the Committee in 2010. Vanuatu's combined initial, second and third reports were discussed in 2007; Vanuatu did file another report in 2015 and is scheduled for Committee review in 2016. Solomon Islands, whose first report was due in 2003, filed its first, and only, report in 2014. ${ }^{31}$

29 CEDAW, Article 18. The CEDAW Committee is made up of 23 experts in gender issues, selected from among the UN member nations. In the 30 years since the Committee began its work, it has progressed from being a mostly overlooked corner of UN activity to being a highly sought-after post. UN member nations vie to get their candidates appointed. Every member of the Committee reads each country report prior to meeting with country representatives, and asks questions during the meeting. Usually, countries then file a written set of responses to the questions. Sometimes, there is a follow-up meeting. The Committee then draws up its 'Concluding Observations', which are phrased in carefully generous terms. The Committee never condemns. It commends the country for good work; it shows 'concern', sometimes 'deep concern'. Nor does it require the country to change; it requests or urges.

30 Article 2 of an Optional Protocol to the Convention, adopted by the General Assembly on 15 October 1999, would give more authority to the Committee, by permitting people or groups who claimed to be victims of 'a violation of any of the rights set forth in the Convention' to bring their complaint to the Committee. Article 8 of the Optional Protocol would enable the Committee to act upon 'reliable information indicating grave or systematic violations by a State Party of rights set forth in the Convention'. However, the extent of the Committee's response to these seems still to be limited to reporting the violations to the state involved and asking for a response from the state (Optional Protocol, Articles 2 and 8, 1999).

31 Convention on the Elimination of All Forms of Discrimination against Women, 63rd Session (15 Feb 2016 - 4 Mar 2016). The slowness of small countries to file reports is not necessarily a sign of their unwillingness to promote gender equality. The reporting process is a major undertaking, requiring time, resources and information from many governmental departments and ministries. Moreover, representatives from reporting countries are supposed to travel to UN headquarters in New York to present their reports, and most countries do demonstrate their respect for the CEDAW Committee by sending a high-ranking team. For example, the 2010 PNG delegation was headed by Dame Carol Kidu, Minister for Community Development, and included the State Solicitor, PNG's Ambassador to the United Nations, a Principal Advisor to the Prime Minister, and the heads or deputy heads of the Departments of Labour and Employment, National Planning, Community Development, Education, Health, Foreign Affairs, and Agriculture, or of key divisions of those departments. 
The potential shortcomings of the implementation process are not singular to CEDAW; non-enforceability is a characteristic of international law. Much like pre-colonial customary law in Melanesia, international law is not supported by institutionalised enforcement mechanisms: there are, for all intents and purposes, no courts and no police charged with the authority to enforce international law. ${ }^{32}$ How, then, are the principles of international law turned into effective action by and within states? One way is through the agency of judges in state courts. In the next section of this chapter, I describe the methods judges in Melanesia are using to interact with and interpret CEDAW's doctrines in order to integrate CEDAW into state law and turn it into a binding domestic legal obligation.

\section{The approaches of Pacific Islands courts to CEDAW}

Despite their different approaches, Merry and Meyersfeld concur on one point. Both recognise that, for international norms to have an effect within states, they must be, in Merry's words, 'translated', and, in Meyersfeld's words, 'interpreted and internalized'. Judges of the state courts of the Pacific Islands nations are uniquely placed to translate the culture of international human rights law into the local context, because the judges themselves partake of both cultures. As judges, they have been socialised into a legal culture that, like the culture of international agencies, foregrounds the values of universality and rationality. In addition, as members of their local communities, they ought to have some feel for the frictions, tensions and possibilities provided by local cultures, and they ought to be more able than are the faraway CEDAW experts to understand how to meld the two, and how to use their own cultures' malleability to CEDAW's advantage.

We can trace with some degree of accuracy the interactions of CEDAW and the courts, as well as the results of those interactions, because the judges write about it for us. The written judicial decision exists for many reasons. Most immediately, its purpose is to convince the parties

32 The recent establishment of international and multilateral human rights and criminal law courts prove the point. The courts have jurisdiction only over those states that voluntarily accept their jurisdiction; many states, including the United States, have not. And their decisions, while formally like those of state courts, are unenforceable absent the agreement of the subject state. 
to the case that the court decided it correctly. A second, equally key reason is to explain the new law to lower courts and lawyers, so in future they will interpret and apply it similarly. Judges are not supposed to decide disputes on the basis of who is nicer, or more sympathetic, or more like the judge; they are not even supposed to decide on the basis of what would be the best outcome for the parties or for their community. Judges are supposed to apply the law, and to do this they need to know just what the law is and how it applies. Statutes go only so far; they give rules, but they don't interpret them. That's what judicial opinions do; they become precedents, that courts and lawyers can rely on to shape the outcome of later cases. ${ }^{33}$

However, precedent does not work with an iron hand; the common law admits, even encourages, responsiveness to changing circumstances, as long as the changes are neither too precipitate nor too extensive. And that is another of the reasons why judges write opinions. Judges who wish to alter the interpretation or application of a long-standing norm, so as to make it better fit the present, can find, in the words and thoughts, the analogies and allusions, of earlier opinions, support for doing so. ${ }^{34}$ And, in their own decisions, they can explain their reasons for adopting a new or slightly different interpretation, in ways that may persuade, or at least deflect some of their readers' criticism. ${ }^{35}$

The recognition that gender violence is not only wrong but unlawful, presents such a moment for judges in Pacific Islands nations: a moment when it might be up to them to reinterpret or reapply old commonlaw doctrines in new ways, perhaps even to make new common law. CEDAW gives judges both a reason to do so and support for doing it. Judges in Pacific Islands courts have sometimes acknowledged CEDAW's existence and used it to support their decisions, sometimes refused to, in a variety of different contexts, ranging from the expected (including cases involving marriage and the custody of children, domestic violence, and rape) to the surprising (such as disputes over customary land, the enforcement of collective bargaining agreements, and deportation proceedings). A court's choice not to use CEDAW is just as telling as a choice to use it. ${ }^{36}$

33 James Boyd White, 1995, 'What's an opinion for?' University of Chicago Law Review 62(4): 1363-69, pp. 1363-64; see also Patricia M. Wald, 1995, 'The rhetoric of results and the results of rhetoric: Judicial writings', University of Chicago Law Review 62(4): 1371-419, p. 1376.

34 Wald, 'The rhetoric of results and the results of rhetoric: Judicial writings', p. 1400.

35 Ibid., pp. 1394-98.

36 Ibid., p. 1376. 


\section{How the courts justify their adoption of CEDAW into domestic law}

An international treaty or convention, such as CEDAW, is meant to be enforceable by the courts and law enforcement authorities of each ratifying state as if it were the law of that state. But, technically, that enforcement cannot occur merely because the executive arm of the state government has ratified the convention. It becomes enforceable, as part of the state's law, only after the state's legislative body has expressly adopted it as such. Very few legislatures have taken that second, crucial step of enacting CEDAW into domestic legislation.

That, supposedly, leaves the courts without the power to enforce the treaty or covenant; unable, that is, to hold people accountable if they do something that conflicts with or violates the convention. But courts have found ways to incorporate international covenants or conventions into their decisions, even when parliaments have not expressly adopted them. One method is for the court to rule that, while not precisely or expressly enacting an adopting statute, the legislature has done something that can be characterised as close enough to such an enactment to justify the court in treating the convention as if it were statutory. Another way is for the court to decide that the legislature's express adoption of the Convention in one area of law implies that the legislature intended it to be adopted and enforced in other areas as well. These and other methods are more fully described below.

A case from Fiji illustrates how judges can sometimes find a way to introduce an international convention into their opinions, even when the particular domestic law that the court is enforcing contains no mention of it. Courts are supposed to obey and apply their nation's statutes; they can't ignore them or make a decision that flouts the applicable statute. But, in order to apply statutes, courts first have to interpret them, have to figure out just what the statute requires. And courts are authorised to make up their own rules of interpretation. Prakash v. Narayan [2000] FJHC 145 involved the UN Convention on the Rights of the Child (the CRC), not CEDAW, but it illustrates a method of statutory interpretation that can accommodate itself equally well to CEDAW and other international agreements. The case concerned a dispute between a divorcing couple over which of them should have temporary custody of their children during the divorce proceedings. Fiji's Maintenance and Affiliation Act was not clear, 
the court found, on whether the magistrate deciding the divorce action had the authority to make an interim custody order. The CRC contained definitions that would resolve the ambiguity, but counsel pointed out that Fiji's legislature had not yet adopted the CRC into domestic law; for the court to use the CRC in this manner, counsel argued, would be improper, because the court would be usurping the legislature's prerogative. The appellate court held that, to the contrary, it could search for an interpretation of the Act in the CRC, even though it had not been adopted into Fijian domestic law, because, as the judges of the High Court of Australia had said, when faced with a similar choice,

If the language of the legislation is susceptible of a construction which is consistent with the terms of the international instrument and the obligations which it imposes ... then that construction should prevail. So expressed, the principle is no more than a canon of construction and does not import the terms of the treaty or convention into our municipal law as a source of individual rights and obligations. ${ }^{37}$

A neat, and very judicial, splitting of hairs. ${ }^{38}$

But the courts are not always willing to split those particular hairs. Tepulolo v. Pou [2005] TVHC 1 was a Tuvaluan case that also centred on a custody dispute. The Island Court gave custody to the father, and the mother appealed, saying that the statute in question, the Native Lands Ordinance, violated both the CRC and CEDAW by providing

\section{Minister of State for Immigration and Ethnic Affairs v. Ah Hin Teoh [1995] HCA 20.}

38 A similar method was employed in Fijian Teachers Association v. President of the Republic of Fiji Islands [2008] JFHC 59. Here, the controversy was between the union and a post-coup government that wanted to introduce by fiat new labour legislation, which would abrogate the collective bargaining agreement in place between the union and the government. The union wanted the decree stayed, at least until a court could rule on its validity. Justice Scutt stated that, in order to decide whether to stay the effect of the decree, she must balance the public interests for and against a stay. One of the key provisions of the new decree was the award of generous, paid maternity leave. Although the Fijian Parliament had not made CEDAW generally applicable, it had, in the Family Law Act of 2003, provided specifically that courts should have regard to CEDAW in carrying out the provisions of that Act. Among CEDAW's provisions is a requirement that states grant women adequate maternity leave. Justice Scutt held, 'If it is in the public interest to affirm these rights under the Family Law Act, then it appears to me that it would, could or should be accepted as in the public interest to affirm them as relevant under employment or industrial law also' (p. 49). She did not go so far as to treat CEDAW as if it had become part of Fijian law, which she could do only if Parliament had adopted it for all purposes. She held merely that courts could look to certain provisions of CEDAW as examples of topics, like maternity leave, that the government considered to be matters of public interest. Because the edict covered maternity leave, it was, on balance, more in the public interest to allow it to proceed than to stay its effectiveness, pending more court hearings. 
that, after the age of two, the child of 'a father being a native' shall reside with the father or his relations and shall in accordance with native customary law inherit land and property from his father in the same way as the father's legitimate children. Although the Government of Tuvalu had ratified both Conventions, parliament had yet to enact any law to bring 'those obligations into effect' ${ }^{39}$ The appellate court noted that Tuvalu's Interpretation Act provides, 'A construction of a written law which is consistent with the international obligations of Tuvalu is to be preferred to a construction which is not ${ }^{\prime} .^{40}$ But the court stated that 'will only be relevant where there is an apparent ambiguity in the laws of Tuvalu which requires the court to determine the true construction of the law'. ${ }^{41}$

And the court held there is no ambiguity in the Native Lands Ordinance; contrary to the principles of international law it might be; unclear it is not. Judges focus on the effect that the case they are deciding will have on the law; the parties to those cases, however, focus on the effect that the law — and the judge - has on them. In this case, a judge's interpretation of the law resulted in a Tuvaluan mother losing not only custody of, but almost all contact with, her six-yearold son, because the father took him to live in New Zealand.

When judges declare that they will not apply CEDAW, it is usually because of some other value inherent in the legal culture that the judge finds more important. Thus, in Hatilia v. Attorney General [2012] SBHC 101, a Solomon Islands case, the plaintiff's husband had earlier lost a court case in which he tried to stave off deportation; the plaintiff then brought suit, claiming that her husband's deportation would harm the rights guaranteed to her by the Solomon Islands Constitution and CEDAW. The court responded that the arguments had been fully aired in the earlier case, which, though it was brought by her husband, focused on the same Constitutional provisions as she was presenting, and that, since the CEDAW provisions were simply analogues of the Constitutional guarantees, those had, for all intents and purposes, already been litigated as well.

\footnotetext{
39 Tepulolo v. Pou [2005] TVHC 1, p. 8.

40 Ibid.

41 Ibid.
} 
Sometimes, though, one can detect in the judge's approach to the case that the reason she is not applying CEDAW is because she, personally, disagrees with CEDAW. For example, in Police v. Apelu [2010] WSSC 178, a Samoan case, the defendant was a woman, accused of performing abortions - a crime still in Samoa. Her counsel argued, 'quite passionately' the court noted, 'that while abortion is against the law of this country, there exists a social need for $\mathrm{it}^{\prime} .{ }^{42}$

Counsel also pointed out that Samoa's approach to this complex issue is contradictory. This country is party on the one hand to the United Nations Convention on the Rights of the Child which focuses on safeguarding of children and a child's right to life and co-existence but on the other hand it is also party to CEDAW or the United Nations Convention on the Elimination of all forms of Discrimination against Women which advocates the right of a women to decide what is in her best interests. ${ }^{43}$

The court was moved neither by counsel's passion nor by his arguments:

Notwithstanding our beliefs in relation to what I concede is a complicated and controversial subject it is a criminal offence to do what the defendant did. People in any societal grouping are not free to decide whether or not to follow the law depending on their personal views. No one is free to say I will follow that law because I think it is a good law but not that law because I think it's a bad law. If we went down that path we would end up in a society subject to a lot of chaos. This country through its elected representatives namely Parliament has chosen to take a pro-life stand and have legislated against abortion except when it is necessary to preserve the life of the mother ... Parliament having enacted that law, the court's duty is beyond question, it is required to enforce the laws of the land. The rightness, wrongness or morality of such a law is debated in the building next door [in Parliament], not in this one. ${ }^{44}$

The court seems to be saying that, at least for purposes of Samoan criminal law, CEDAW does not exist. If it did, then as defendant's counsel had attempted to argue, she would not be acting solely out of personal belief; she'd be acting in line with the law.

\footnotetext{
42 Police v. Apelu [2010] WSSC 178, p. 2.

43 Ibid.

44 Ibid.
} 
Courts can be effective translators of the norms and values of international law, implanting international norms into their country's domestic legal system, even when parliament has failed to enact a statute expressly adopting the international law. Occasionally, a court will take wing, and dare to put itself way out ahead of parliament. Such was a recent Papua New Guinea National Court decision by Justice Cannings. In Sukuramu v. New Britain Palm Oil Ltd [2007] PGNC 21, an employee was fired for threatening his supervisor and, in a rage after that argument, damaging the company's property. Good cause to dismiss him, perhaps - except, he argued, the implied terms of his employment contract required that he be given a hearing before he could be dismissed. However, the contract contained no provisions requiring that an employer be fair or just. The errant employee argued that the common law of Papua New Guinea (which is referred to in the Papua New Guinea legal system as the 'underlying law') ought to be changed from its faraway English beginnings; it ought, the employee argued, to reflect the circumstances and values of Papua New Guinea. And how to find what those circumstances and values are in a case involving the termination of an employee contract? Look, the employee said, to the Convention of the International Labour Organization, to which Papua New Guinea is a signatory, and which, among other things, prohibits the termination of employees before they are given an opportunity to defend themselves. Justice Cannings agreed with the erstwhile employee, and held that, based on that treaty, the employee ought to have been granted a hearing. Parliament had not yet acted to give that treaty the status of domestic law. But, Justice Cannings held, that was not an impediment:

In the present case there is no Constitutional Law or Act of the Parliament that gives ILO Convention ... the status of municipal law. Therefore the question of whether its provisions have been breached is non-justiciable. However, its significance lies elsewhere. PNG is a party to it and has an obligation as a matter of international law to make laws to give it effect, except to the extent that its provisions are given effect in some other manner, including by court decisions. If I formulate a rule of law, as a court decision, that gives effect to ILO Convention No 158 I will be helping PNG discharge its international law obligations. I will be developing the underlying law in a manner consistent with those obligations. PNG's municipal law will be made consistent with international standards. ${ }^{45}$ 
This decision goes very far afield from the maxim that international agreements become domestic law only when the legislature has acted expressly to give them that status. But, even here, the judge feels called upon to explain himself in conventionally legal terms. He is not anarchically changing that rule, he says; he is, indeed, following it-just in a rather eccentric way.

\section{How the courts use CEDAW}

In the preceding section, we looked at the various arguments courts make to justify their decision to use CEDAW as if it had the force of local law, even where the legislature has not formally given it that force. Having decided that they will use CEDAW, courts go on to make use of it in a variety of different ways. There are at least four ways in which a court can make use of CEDAW and other international laws. First, the court can use CEDAW as a precedent - much as if it were the ruling in an earlier case- helping the court to interpret and apply the common law, Constitutional law or statutory law. Second, the court can cite CEDAW as an authority for making changes in the common law. Third, if statutes or custom contain provisions or norms that conflict with CEDAW, the court can declare those no longer in effect. And, finally, the court can treat CEDAW as it would any domestic statute, making a breach of any of its provisions, either by an individual or by the government, unlawful. In each of these circumstances, as Meyersfeld says, the courts are engaging in a process of infiltration, by which CEDAW is internalised into the country's domestic legal system. And, in each of these circumstances, as Merry points out, the international law undergoes a process of translation and change.

\section{CEDAW as precedent}

The court can use an international convention as precedent, to buttress the court's view of the way in which a statute or constitutional provision should be interpreted. In State v. S.N.M. [2011] FJHC 26, for example, Justice David Goundar of the Fiji High Court had to decide whether to issue a restraining order, prohibiting a husband convicted of wife-beating from approaching his de facto wife. The husband argued earnestly that he'd learnt his lesson by going to prison and was willing to undergo counselling; his wife, however, did not want anything to do with him. The Domestic Violence Decree, which had 
recently been issued by the Prime Minister, provided that one of its objects was 'to implement the Convention on the Elimination of All Forms of Discrimination against Women' which was promulgated 'to ensure the protection, safety and wellbeing of victims of domestic violence' ${ }^{46}$ The judge decided this gave him the authority to issue an order prohibiting the man from going anywhere near his wife.

\section{CEDAW as authority to change the common law}

In Estate of Chinsami Reddy [2000] FJHC 134, the Fiji High Court referenced CEDAW as authority to change the common law. A sister and her two brothers disputed which of them should administer their deceased parents' estate; the sister was considerably more responsible than her devil-may-care brothers, but they pointed out to the court that the common law of England, which Fijian courts are supposed to follow (no matter how ancient the precedent might be), preferred males over females. ${ }^{47}$ The Fijian judge could have found in the sister's favour and, at the same time, upheld hoary precedent, just by pointing out that the brothers' behaviour (one of them had assaulted their father; and then, after his death, ran his sugar cane business into the ground and stripped the farm of its top soil) would cause anyone to have 'substantial objections' to their service as administrators. The Fiji court, however, chose instead to change Fiji's common law, voiding the rule that disfavoured women, and the court cited to CEDAW as the major source allowing it to do so:

Formerly, males were preferred over females ... Fortunately, the law no longer gives effect to such a negative inference about the ability of women to administer an estate, and with the widespread ratification of international human rights instruments such as the United Nations Convention Against the Elimination of Discrimination Against Women, this last principle is of no persuasive value at all. ${ }^{48}$

CEDAW emboldened a Fiji court to make a change in the common law - a change that makes women a little more equal under Fiji common law.

46 Republic of Fiji Islands, Domestic Violence Decree (Decree No. 33 of 2009), Part I, section 6(c).

47 In the Estate of Chinsami Reddy [2000] FJHC 134 (22 December 2000] p. 8, citing Chittendon v. Knight [1758] 2 Cas. Temp. Lee 559.

48 In the Estate of Chinsami Reddy [2000] FJHC 134 (22 December 2000] pp. 8-9. 


\section{CEDAW used as if it were domestic legislation}

In a Vanuatu case, Joli v. Joli [2003] VUSC 63, the judge treats CEDAW essentially the same as he would any Vanuatu domestic statute. A Francophone couple, neither of whom is ni-Vanuatu, are divorcing. They aren't subject to custom, and no Vanuatu statute or common law rule applies. There is an 1882 British statute, but Justice Coventry finds it inapplicable, both because of its Victorian assumption of female inferiority and because the parties, being French, were never subject to British law. The judge turns, instead, to CEDAW, and turns it into a statute, noting that Article 16 provides that:

States Parties shall take all appropriate measures to eliminate discrimination against women in all matters relating to marriage and family relations and in particular shall ensure, on a basis of equality of men and women ... The same rights for both spouses in respect of ownership, acquisition, management, administration, enjoyment and disposition of property, whether free of charge or for a valuable consideration. ${ }^{49}$

Applying that rule to the numerous business and personal assets that the parties held, most of which were in the husband's name, the court found that:

In a marriage of any duration there will be assets which have been bought, created or acquired during the currency of the marriage. In my judgment there is a presumption that all such assets are beneficially owned jointly, no matter whose name they are in or who in fact paid for them, made them or acquired them ... Upon reading the affidavits of both parties and hearing the evidence it is clear that indeed in this case they regarded their contributions and activities as building up the family assets and the use of those assets as being for the advancement of the welfare of the family as a whole ... I cannot find on the evidence anything to rebut the presumption that all the assets in dispute are beneficially owned by both parties. Accordingly I rule that all the assets listed as being in dispute are matrimonial assets for the purposes of negotiation for a settlement. ${ }^{50}$

The cases reviewed in this section demonstrate that judges do use international law as if it was domestic law. They use it, as they would the common law, as precedent for their decisions; they use it, as they

49 Joli v. Joli [2003] VUSC 63, p. 4, citing CEDAW Article 16(1).

50 Joli v. Joli [2003] VUSC 63, p. 7. 
would a statute, as the rule that they are supposed to apply to the parties before them. By shaping their decisions according to the rules of international law, they change the outcomes for the parties. If, for example, the Vanuatu court had not chosen, in Joli $v$. Joli, to treat CEDAW as if it were a governing statute, Mr Joli might have ended up with practically all the couple's property, because most of it was held in his name. Similarly, if the Fijian court had not chosen, in Estate of Reddy, to treat CEDAW as precedent, the improvident brothers might have become administrators of their father's estate. Instead, their caring and responsible sister was put in charge of the farm. Sometimes, the parties know that the judge has used international law to decide the case; often, the lawyers know, but the parties don't. But the result is the same. A domestic rule of law has been changed, and the outcome for the parties is different from what it might have been. A principle of international law has become domestic law.

Nor are these merely changes to the law itself. Changes to the law do ultimately affect behaviour and even values. Will the mere adoption by a court of rules against domestic violence significantly decrease wife beating? Probably not on its own. But, gradually, and to a greater or lesser extent, individuals do shape their expectations to match what the law will allow them. As divorce lawyers and their clients learn that the courts will award to the wife a share of the property acquired during the marriage, more women will ask for their share; more women might even decide to divorce. As the word spreads that women can be administrators and executors of estates, more of them will ask for the job-and for similar jobs. In Meyersfeld's perfect choice of a descriptive term, international law 'infiltrates' national legal systems and culture through the medium of judge-made law.

\section{CEDAW in different circumstances}

We have now seen the different ways in which courts can useor refuse to use - CEDAW. The next question that requires answering is whether courts use CEDAW differently depending on the area of law and culture involved-depending, in particular, on whether the case involves state law or custom. In this section, I will analyse the different ways in which state courts use CEDAW in response to three different areas in which gender discrimination occurs: in the rules governing title to customary land, in the rules about who gets 
to choose the person a young man or woman will marry, and in the rules about the kind of evidence needed to prove a rape case. The first two areas involve conflicts between CEDAW and custom; the third involves conflicts between CEDAW and state law.

\section{CEDAW and customary land tenure}

In cases involving customary land tenure, the Vanuatu courts insist that they are changing custom to make it comport with CEDAW. In fact, however, in these cases, custom is altered very little, and women's position remains subordinate to men's.

CEDAW has been used in a number of Vanuatu cases involving dispute over customary land. In each of the reported cases, the clearest and most persuasive evidence of customary ownership would require the court to recognise the right of a woman to inherit the land and, in each case, one or more of the (male) disputants argued that customary law prohibited women from inheriting land. The court responded that CEDAW required custom to change, and gave the land to the woman's clan. In one of the cases, Awop v. Lapemal [2007] VUIC 2, one of the witnesses was an older man; the judge described the old man's testimony:

In his concluding words he stressed that the basis for land ownership in the island of Malekula is based on a monarchy type of system whereby a daughter marrying another tribe cannot claim land ownership. He accuses the Convention on Elimination of all Forms of Discrimination Against Woman (CEDAW) to have caused serious conflict and disruption with the custom system long practiced. ${ }^{51}$

The ni-Vanuatu judge dealt with this argument, summarily:

It is apparent that those advanced submissions are culturally oriented upon the patrilineal structure patronising men over women. Unfortunately, such a standard norm cannot bypass the applicable laws of this country as discussed below ... Firstly, Vanuatu has ratified the Convention on the Elimination on Discrimination Against Women by the Ratification Act of Parliament no. 3 of 1995. This international law requires that every signatories [sic] to it must take all necessary steps to condemn and wipe away [all] forms of discrimination against females. This court cannot allow custom to discriminate against women..$^{52}$ 
But, in fact, the court did not go so far. It held only that 'if, there are no more surviving male descendants' of the original ancestor then 'ownership will pass on to the matrilineal offspring'. ${ }^{53}$ The court is allowing the winning clan to trace its rights through a woman only when no men are alive at the time. And the woman in question does not herself gain any control over the land; that went to her male children, thus continuing the ownership of the land in their father's line. Still, the case does mark one small step in the direction of gender equality trumping custom.

\section{CEDAW and arranged marriages}

There are at least five cases concerning the custom among Fiji's Indian community of arranged marriages. ${ }^{54}$ All five cases were decided in 2008 and 2009 by a single judge, Justice Jocelynne Scutt of the High Court of Fiji, Family Division. Dr Scutt is a leading scholar, teacher and barrister in Australia, specialising in women's issues; she has written extensively on issues of women's equality and gender violence. ${ }^{55}$ It is, therefore, not surprising that, in each of these cases, she voided the arranged marriage on the grounds that it violated CEDAW.

All the cases involved Fijians in their 20s who had been married at the behest of their parents and relatives, and who wanted out; they were looking not for a divorce (none of them wanted to be known as a divorced person) but for an annulment (which, at law, means the marriage never happened). There are only a few grounds for annulment; one of them is duress or coercion. The courts of both England and Fiji had interpreted the statute to require a party who wanted an annulment on the ground of duress or coercion to prove that they had been physically beaten, injured, terrorised, or put in fear of such treatment. Justice Scutt changed that statutory interpretation; she held that no proof of physical injury or threat was needed, because the custom of marriages arranged by parents is itself coercive, especially for young people who want to do what their family and society ask of them.

\footnotetext{
53 Ibid., p. 4.

54 FJN and MRK [2009] FJHC 94. LK and JVR [2009] FJHC 60. NK and ZMR [2009] FJHC 95. $P P$ and $R P$ [2009] FJHC 72. RPN v. SPP [2008] FJHC 166. TZS and FSB [2009] FJHC 97. VDC and VNS [2009] FJHC 69.

55 Jocelynne Scutt, 2012, 'Leadership interviews: Interviews about the glass ceiling', Australian Centre for Leadership for Women.
} 
She also held that the Fijian courts ought not to be supporting arranged marriages, because 'in Fiji, [annulment] applications are heard against the backdrop of section 26 of the Family Law Act', which incorporates CEDAW into the law of Fiji, and requests courts to take CEDAW into account in reaching their decisions:

The international conventions and instruments emphasise the importance of agency in entering into the marriage relationship. Referred to explicitly in the Family Law Act, the Convention on the Elimination of All Forms of Discrimination against Women is emphatic as to a woman's 'right to choose a spouse and enter freely into marriage', this right to choose and the freedom of entering into marriage being 'central to her life and her dignity and equality as a human being'..$^{56}$

\section{CEDAW and rape}

CEDAW has been cited in a number of cases involving convictions for rape. One of these cases, State v. Bechu [1999] FJMC 3, from Fiji, involved custom, or at least customary attitudes. The defendant admitted in his testimony that the victim had struggled, had said she did not want sex with him, and that he had had to punch her to get her to give in - and then he pleaded not guilty on the grounds she'd consented. In sentencing the defendant to a five-year prison term, the judge felt called upon to explain to the defendant that, when a woman says no, she means no:

Women are your equal and therefore must not be discriminated on the basis of gender. Men should be aware of the provision of 'Convention on the Elimination of all forms of Discrimination against Women' (CEDAW), which our country had ratified in $1981 \ldots$ The old school of thoughts, that women were inferior to men; or part of your personal property, that can be discarded or treated unfairly at will, is now obsolete and no longer accepted by our society. ${ }^{57}$

The judge did not rule that CEDAW had made any particular customary norm or practice unlawful, but he enlisted international law on the side of social change.

$56 N K$ and $Z M R$ [2009] FJHC 95, p. 9, citing CEDAW Article 16(1)(b).

57 State v. Bechu [1999] FJMC 3, p. 9. 
In most of the rape cases, however, CEDAW has played a more substantive role. Until very recently, statutory and common-law rules regarding rape contained many gender-biased elements. For example, most courts required there be evidence that a woman was beaten, or threatened with serious physical harm, in order to convict a man of rape. A woman who did not fight with her assailant might find the court declaring her assailant not guilty. Similarly, courts refused to convict a defendant on the word of the victim alone; her testimony had to be corroborated by other evidence, such as the testimony of a witness or a hospital examination..$^{58} \mathrm{CEDAW}$ has aided Pacific Islands courts to free themselves from these discriminatory doctrines-but only, it seems, when the court is already disposed to discard the rule.

In Republic v. Timiti \& Robuti [1998] KIHC 1, a Kiribati judge refused to do away with the corroboration rule, though he left the door open for doing so in the future. In Kiribati, as in $\mathrm{PNG}^{59}$ courts may convict a rapist on the uncorroborated testimony of his victim, but only if the judge has first reminded himself that he must be very cautious about believing women who cry rape. The prosecutor argued that this rule, which allows many rapists to go free, should be discarded, because it applies only to rape and sexual abuse; the courts do not question the uncorroborated testimony of robbery victims, victims of attempted murder, assault or, for that matter, any other crime of violence. And rape, the prosecutor pointed out, is almost always a crime perpetrated on a woman. Therefore, the prosecutor concluded, the corroboration rule 'violates the rights of women in that it denies them the equal protection of the law guaranteed by section 3 of the Constitution' ${ }^{60}$ Furthermore, the prosecutor continued, 'In interpreting the law on this point', the judge 'ought to follow the principles formulated in the Convention on the Elimination of All Forms of Discrimination against Women' ${ }^{61}$ The judge refused to give up the 'uncorroborated testimony' rule. However, he did not defend the rule, did not try to argue that it was not discriminatory. Instead, he performed a favourite judicial sleight of hand: in this case, the judge pointed out, the woman's testimony had been corroborated - there were witnesses who had seen her and

58 Jean Zorn, 2010, 'The paradoxes of sexism: Proving rape in the Papua New Guinea Village Courts', LawAsia Journal 2010: 17-58.

59 Ibid.

60 Republic v. Timiti \& Robuti [1998] KIHC 1, p. 4.

61 Ibid. 
talked to her right after the rape, when she was still dishevelled, distraught and dazed. Since that was the situation, the judge said, he had in fact not used the 'uncorroborated testimony' rule. So this was not, the judge concluded, the appropriate case in which to contest its validity.

But in Balelala v. State [2004] FJCA 49, Fiji's Court of Appeal took the opposite position. The defendant had been convicted of rape and appealed on the ground that, contrary to the rule then in force, he had been convicted despite the fact that the victim's testimony had not been corroborated. The three-judge appellate panel found that there had been corroboration; the defendant had confessed to the rape, and that, the panel held, is corroboration enough. Having found corroboration, the court could have stopped there, as the Kiribati court had done in Republic $v$. Timiti \& Robuti. It had done all it needed to do to uphold that defendant's conviction.

But the court went further. It discussed the history of the corroboration rule, not only in Fiji, but in England, New Zealand and Canada as well, pointing out that the rule existed because of gender discrimination: 'The rule of practice which required corroboration ... in cases of sexual assault, depended on a generalisation that female evidence in such cases is intrinsically unreliable. ${ }^{62}$ The court also noted that in these jurisdictions, as well as in many others, the rule has been abrogated, because it is counter productive, confusing and both discriminatory and demeaning of women' ${ }^{63}$ The practice of other jurisdictions gave the court support for repealing the rule, but it found its most urgent support in section 38(1) of the 1997 Fiji Constitution, which provided, 'a person must not be unfairly discriminated against ... on the ground of his or her ... gender'. Did the uncorroborated testimony rule unfairly discriminate against women? The court held that it did, because section 43(2) of the 1997 Constitution required courts to interpret the Constitution with 'regard to public international law', and the court found: 'All major human rights instruments establish standards for the protection of women, including a prohibition on any form of discrimination against them: e.g. the Convention on the Elimination of All Forms of Discrimination against Women. ${ }^{64}$ CEDAW had given

62 Balelala v. State [2004] FJCA 49, p. 14.

63 Ibid., p. 22.

64 Ibid., p. 24. 
the Fiji Court of Appeal the interpretive tools it needed to conclude that the 1997 Fiji Constitution required an end to the uncorroborated testimony rule.

\section{CEDAW and child sexual abuse}

In Papua New Guinea, a new statute increasing the penalties for child sexual abuse, and making convictions easier to obtain, was enacted in 2002. Its backers drew their inspiration from CEDAW. Thus, in this area of law, the courts have the necessary legislative backing to enforce CEDAW, and do not need to resort to the kinds of arguments I've outlined earlier in this chapter.

Dame Carol Kidu played the key role in translating into domestic law some of the key provisions of CEDAW on rape and the sexual abuse of children, when she introduced the Sexual Offences and Crimes Against Children Act of 2002 into parliament, and shepherded it to enactment. Although she was a Cabinet member, she had so little support from government for the bill that she had to introduce it as a private member's bill. ${ }^{65}$ The Act has changed the law on child sexual abuse, making the sexual penetration of a child under the age of 16 an offence punishable by a prison term of up to life imprisonment, and adding the offence of sexual touching, which does not require penetration, and is punishable by a prison term of up to 12 years if the child is below the age of 12 , and also if the child is between the ages of 12 and 16 and the offender was in a relationship of trust, authority or dependency with the child.

65 The Act does not itself mention CEDAW, but Dame Carol Kidu stressed CEDAW's influence when she introduced the bill into parliament:

In 1995, Papua New Guinea ratified the United Nations Convention [on the Elimination of] All Forms of Discrimination and Violence Against Women. As a nation we have both a regional and international commitment to address this important issue ... Mr. Speaker, we as parliamentarians must speak out loudly against all violent sexual assaults because they not only can cause us physical injury; they also destroy our selfdignity and pride. Declaring acts as criminal ... gives us a moral denunciation of the unacceptable conduct. This can have a very significant impact on shaping the changing values of our young nation. We as parliamentarians have an extremely important role to play in this regard; passing, drafting or clarifying laws that criminalize violence particularly against women and children but also to all violence is an important step in re-defining the limits of acceptable behaviour (as quoted in The State $v$. William Patangala [2006] PGNC 43; N3027). 
In two leading Papua New Guinea cases, Justice Salatiel Lenalia of the Papua New Guinea Supreme Court not only applied the stringent new provisions, but quoted Dame Carol's Act approvingly when he did so. Thus, the Act and Dame Carol's support of it have had both an expressive and an implementing effect.

Both cases involved the 'sexual touching' of a young girl by an older relative with whom the girl was living and who was, in effect, the girl's guardian. Though two years apart (one case was heard in 2006, the other in 2008), both were tried in the National Court in Kokopo, before Justice Lenalia. By citing CEDAW when she introduced the bill, Dame Carol began the political work that Merry calls translation, pointing out to parliament and NGOs the key transformative role that CEDAW could play in helping to end Papua New Guinea's culture of violence against women and girls. And when Justice Lenalia picked up the idea from her, first by interacting with CEDAW and interpreting its doctrines 'to give them a domestic meaning', he completed the process of integrating CEDAW into domestic law, giving CEDAW the status of an 'internally binding domestic legal obligation' ${ }^{66}$

The first of the cases to be decided by Justice Lenalia was The State $v$. William Patangala [2006] PGNC 43; N3027. ${ }^{67}$ The defendant pleaded guilty to the crime of sexually touching ${ }^{68}$ a 14-year-old girl; Justice Lenalia's task was to decide on a sentence. He could have sentenced the defendant to 12 years; after all, a relationship of trust existed: the victim was the defendant's niece, the daughter of his wife's sister. ${ }^{69}$ Leaning toward a shorter sentence were the defendant's freely given confession and his payment to the victim's family of twice the amount of money and shell compensation ordered by the village councillor. On

66 Koh, 'Why do nations obey international law?' p. 262, quoted in Meyersfeld, Domestic Violence and International Law, p. 258.

67 Actually, State $v$. Patangala was not the first case involving the sexual touching of a minor to come before Justice Lenalia. He'd decided another such case a year earlier-The State $v$. Adrian Amos, CR No. 701 of 2005-but that case was not published.

68 The new law provides two levels of sexual crimes against children: those involving penetration and those involving only touching. The crime of 'sexually touching' a child is defined in section 229B of the Criminal Code: 'when a person, for a sexual purpose, touches with any part of his/her body, the sexual parts of a child under the age of 16 years, or compels a child under that age to touch the sexual parts of that person with any part of his/her body.'

69 Section $6 \mathrm{~A}(2)(\mathrm{c})$ of the Criminal Code contains a list of persons in positions of trust, authority or dependency, including teachers, parents, guardians, aunts or uncles and a number of others. 
the side of a longer sentence were the existence of that relationship of trust and the fear of the victim and her parents that, if the defendant were not suitably punished, he would assault her again.

In weighing these competing concerns, Justice Lenalia took into account social and legal considerations. First, he noted that the Act was new; it had come into operation less than three years before. Parliament had enacted it in response to the disturbing prevalence in Papua New Guinea of 'sexual abuse of our children both very young girls and boys', and it was imperative, the judge said, to publicise the existence of the new law and to make sure it was applied..$^{70}$ Papua New Guinea had entered a new reality, he pointed out, one characterised by a new respect for the human rights of women and children. And, here, he quoted Dame Carol's speech when she presented the Act to parliament. At the moment that Justice Lenalia quoted that speech in a judicial decision, the integration of CEDAW's provisions into the domestic culture had taken a major step forward. Dame Carol, parliament and the courts were now united in translating CEDAW's provisions from general principles of international law into doctrines with 'a domestic meaning' ${ }^{.1}$

Justice Lenalia ultimately decided to sentence the defendant to a total of four years, with only the first year to be served in prison, the next three, subject to good behaviour, on parole. Not a lengthy sentence; but Justice Lenalia was making a start.

The next step was to actually integrate CEDAW's requirements into a common law principle, turning CEDAW into an 'internally binding domestic legal obligation' ${ }^{72}$ Justice Lenalia did so in State $v$. Narakavi [2009] PGNC 109; N 3737, the next of the sexual touching cases that he decided. That case also involved the sexual touching of a 14-year-old girl by an older man. In this case, however, the relationship was even closer than that of uncle and niece. The victim, a first cousin of the defendant's wife, had been raised from the age of four by the defendant and his wife. That made her, Justice Lenalia said, for all intents and purposes, the defendant's daughter, and no relationship of trust, authority and dependency could be closer than that. The defendant

70 The State v. William Patangala [2006] PGNC 43, p. 6.

71 Meyersfeld, Domestic Violence and International Law, p. 258.

72 Koh, 'Why do nations obey international law?' p. 262, quoted in Meyersfeld, Domestic Violence and International Law, p. 258. 
had pleaded guilty, so Justice Lenalia's task was to decide how long a prison sentence he should impose. He needed legal support if he was to sentence this defendant to a term longer than had been the norm, and he found it in two places: in the Criminal Code and in CEDAW. First, he noted the rule from the Criminal Code, section 229B(5), that sexual touching in the context of a relationship of trust, authority and dependency should be met with a longer prison term. He added, 'If the relationship of trust, authority and dependency is very close, like in [this] case, the more serious the case becomes and the higher the penalty should be'. ${ }^{73}$ Second, he said that the integration of CEDAW into the underlying law of Papua New Guinea authorises judges to respond to the widespread problem of sexual violence with longer prison sentences. And, to make sure his audience understood the link, he then quoted Dame Carol's speech again. In the end, Justice Lenalia sentenced the defendant to a term of five years. He also required the defendant to pay compensation to the victim and her family in 'an amount of $\mathrm{K} 1,000.00$ and one live $\mathrm{pig}^{\prime} \cdot{ }^{74}$

\section{Afterthoughts and conclusions}

These cases illustrate the various ways in which judges translate international law precepts into terms accessible to domestic cultures. In the cases involving customary land tenure, the courts' response was more expressive than instrumental: although the change to customary inheritance norms that the courts decreed was itself scarcely momentous, it was a key harbinger of greater changes to come, especially when accompanied by the judges' lectures about the law's recognition of women's equal status. In the arranged marriage cases, Justice Scutt attempted to jettison a customary practice entirely, a clear example of the internalisation of the international norm in the domestic legal system; whether her rulings will be followed by other Fijian judges remains to be seen.

It is in the rape and child abuse cases that CEDAW seems to have had its greatest impact. We do not have enough data to know whether the difference between the land cases and the rape cases is because judges are, with some notable exceptions (such as Scutt on arranged

73 State v. Narakavi [2009] PGNC 109, p. 9.

74 Ibid., p. 11. 
marriages), treading more lightly when it comes to changes in custom than in changes to state law. Or, perhaps, it results from the articulate presence of women's groups, which have been speaking out against rape, wife beating and other forms of gender violence. If so, then internalisation, at least in this area of law, was the result of a fertile cross-breeding, with the activities of NGOs and the opinions of judges strengthening one another.

CEDAW has had a salutary effect on the island nations of the South Pacific, including Papua New Guinea. To say that, however, is not to say very much. To date, CEDAW's effect has been limitedand the problems of women's subordination and of widespread, systemic violence against women remain obdurate and intractable. Nevertheless, it is a beginning. Guided by the analyses of Meyersfeld and Koh, who pointed out that the first impact of an international law on the politics, economy and social ordering of any culture will most likely be found in the legal practices of that culture, I sought for evidence of CEDAW in the decisions handed down by judges of the state courts. And, indeed, I found a number of cases - still scattered, but potentially influential - in which judges have not only mentioned CEDAW's existence, but have actually relied upon it in framing the common law and in applying domestic statutes. In other words, in the Meyersfeld/Koh terminology, judges are aiding the infiltration of this crucially important piece of international law into the domestic legal system.

To date, it would be difficult to argue that CEDAW has had more than that limited effect on the legal systems of the Melanesian states. In Papua New Guinea, for example, despite continued activism by women's groups and other concerned organisations, there has been no legislation implementing any of the provisions of CEDAW since the 2002 enactment of the Sexual Offences and Crimes Against Children Act. The 2013 amendments to the Criminal Code, providing the death penalty for rape, and repealing the Sorcery Act provisions that gave defendants who believed in sorcery a partial defence to the murder of an alleged sorcerer, are cited by some as much needed attempts to put a stop to gendered violence in Papua New Guinea.

Dame Carol's tenure as Minister for Community Development ended in August 2011, when a change of government impelled her into the opposition. That was barely a year after she had shepherded Papua 
New Guinea's 2008 Report to the CEDAW Committee. Under Article 18 of CEDAW, states are expected to report every four years, and the CEDAW Committee, in its Concluding Observations in July 2010, therefore invited Papua New Guinea to submit another report in July 2014. To date, the government has not complied.

The effect of the judicial decisions implementing CEDAW has not gone much beyond the legal system itself. Domestic law has not yet had a significant effect on culture and mores. Throughout Melanesia, and in Papua New Guinea in particular, women are, if anything, more subordinated, more the subjects of violence, less able to compete with any equality in politics or the economy, less likely to receive an education, less likely to receive adequate health care, than ever. The dismal statistics quoted in Papua New Guinea's Report to CEDAW are, if anything, worse. Girls are educated at less than half the rate of boys; village and settlement women die of untreated STDs, such as HIV/AIDS, in alarming numbers; the 2012 general election resulted in a parliament including only four women members. Although women who are the victims of rape and other sexual assaults can now expect some support in the formal state courts, the expense, location and cultural distance of these courts effectively closes them to attempts by women to redress wrongs committed against them. Village Courts are closer and more accessible financially, but their record at responding to women's concerns is questionable at best. ${ }^{75} \mathrm{I}$, like most lawyers, wholeheartedly believe that the law does change behaviour, somewhat, over some period of time, eventually, and can point to numerous instances supporting that belief. So, I am optimistic about the future impact of CEDAW. One wishes that the future would not take so long to arrive.

\section{Acknowledgements}

I wish to acknowledge the help and support of Christine Stewart, whose serious readership took me seriously, which emboldened me to do the same.

75 Jean Zorn, 1994-95. 'Women, custom and state law in Papua New Guinea', Symposium on Women's Rights and Traditional Law: A Conflict, Third World Legal Studies, 1994-95: 169-205. 


\section{References}

Belshaw, Cyril S. 1957. The Great Village: The Economic and Social Welfare of Hanuabada, an Urban Community in Papua. London: Routledge \& Kegan Paul.

Counts, Dorothy, Judith Brown and J. Campbell (eds). 1999. To Have and To Hit: Cultural Perspectives on Wife Beating (2nd edition). Urbana and Chicago: University of Illinois Press.

Cour Pénal Internationale / International Criminal Court. 13 November 2011. Online: www.icc-cpi.int/en_menus/icc/situations $\% 20$ and $\% 20$ cases/Pages/situations\%20and\%20cases.aspx (accessed 1 October 2015).

Crenshaw, Kimberlé. 1991. 'Mapping the margins: Intersectionality, identity politics, and violence against women of color'. Stanford Law Review 43(6): 1241-99.

Dinnen, Sinclair and Allison Ley (eds). 2000. Reflections on Violence in Melanesia. Annandale NSW/Canberra: Hawkins Press/Asia Pacific Press.

Inglis, Amirah. 2009 [1974]. Not a White Woman Safe: The White Women's Protection Ordinance. Port Moresby: University of Papua New Guinea Press (reprint edition).

Jolly, Margaret, Christine Stewart and Carolyn Brewer (eds). 2012. Engendering Violence in Papua New Guinea. Canberra: ANU E Press. Online: press.anu.edu.au? $\mathrm{p}=182671$ (accessed 3 November 2014).

Jowitt, Anita and Tess Newton Cain (eds). 2003. Passage of Change: Law, Society and Governance in the Pacific. Canberra: Pandanus Books.

Koh, Harold Hongju. 1997. 'Why do nations obey international law?' Yale Law Journal 106: 2599-611.

Luluaki, John Y. 2003. 'Sexual crimes against and exploitation of children and the law in Papua New Guinea'. International Journal of Law, Policy and the Family 17(3): 275-307. 
Merry, Sally Engle. 2006. Human Rights and Gender Violence: Translating International Law into Local Justice. Chicago: University of Chicago Press.

Meyersfeld, Bonita. 2012. Domestic Violence and International Law. Oxford: Hart Publishing.

Myres, S. McDougal, Harold D. Lasswell and Lung-chu Chen (eds). 1977. Human Rights and the World Public Order: The Basic Policies of an International Law of Human Dignity. New Haven: Yale University Press.

Pacific Islands Legal Information Institute. Online: www.paclii.org (accessed 1 October 2015).

Papua New Guinea Consolidated Legislation. Online: www.paclii.org/ pg/legis/consol_act/cotisopng534/(accessed 1 October 2015).

Scutt, Jocelynne. 2012. 'Leadership interviews: Interviews about the glass ceiling', Australian Centre for Leadership for Women (23 May). Online: www.leadershipforwomen.com.au/empowerment/ leadership/item/dr-jocelynne-scutt-2 (accessed 1 October 2015).

Toft, Susan (ed.). 1985. Domestic Violence in Papua New Guinea. Monograph No. 3. Port Moresby: Papua New Guinea Law Reform Commission.

Wald, Patricia M. 1995. 'The rhetoric of results and the results of rhetoric: Judicial writings'. University of Chicago Law Review 62(4): 1371-420.

White, James Boyd. 1995. 'What's an opinion for?' University of Chicago Law Review 62(4): 1363-71.

Wolfers, Edward P. 1975. Race Relations and Colonial Rule in Papua New Guinea. Ann Arbor: University of Michigan Press.

Zorn, Jean. 1994-95. 'Women, custom and state law in Papua New Guinea', Symposium on Women's Rights and Traditional Law: A Conflict. Third World Legal Studies, 1994-95: 169-205.

- 1999. Women, Custom and International Law in the Pacific. Occasional Paper No. 5, Port Vila: University of the South Pacific School of Law Faculty Colloquium. 
2010. 'The paradoxes of sexism: Proving rape in the Papua New Guinea Village Courts'. LawAsia Journal 2010: 17-58.

- 2012. 'Engendering violence in the Papua New Guinea Courts: Sentencing in rape trials'. In Engendering Violence in Papua New Guinea, ed. Margaret Jolly, Christine Stewart and Carolyn Brewer, pp. 163-96. Canberra: ANU E Press. Online: press.anu.edu.au/ publications/engendering-violence-papua-new-guinea (accessed 3 November 2014).

\section{United Nations Documents}

Committee on the Elimination of Discrimination against Women (CEDAW), Thirty-eighth Session, Concluding Observations: Vanuatu (CEDAW/C/VUT/CO/3) (11 June 2007).

- Forty-sixth Session, Summary Record of the 940th Meeting, Held 22 July 2010 (CEDAW/C.SR.940) (October 2010).

—. Forty-sixth Session, Concluding Observations: Papua New Guinea (CEDAW/C/PNG/CO/3) (30 July 2010).

- 2009. 'Consideration of reports submitted by States parties under article 18 of the Convention on the Elimination of All Forms of Discrimination against Women: Combined initial, second and third periodic report of State parties: Papua New Guinea'. CEDAW/C/ PNG/3, p. 28, item 2.2. Online: www.bayefsky.com//reports/papua_ cedaw_c_png_3_2008.pdf (accessed 24 November 2014).

- List of issues and questions with regard to the consideration of periodic reports: Papua New Guinea, CEDAW/C/PNG/Q/3 (15 September 2009).

Convention on the Elimination of All Forms of Discrimination against Women, G.A. Res. 34/180, U.N. GAOR, 34th Sess. Suppl. No. 46, at 193, U.N. Doc. A/34/46 (1979).

Convention on the Elimination of All Forms of Discrimination against Women, Sixty-third Session (15 Feb 2016 - 04 Mar 2016). Online: tbinternet.ohchr.org/_layouts/treatybodyexternal/SessionDetailsl. aspx?SessionID=1007\&Lang=en (accessed 18 April 2016). 
Convention on the Elimination of All Forms Discrimination against Women, General recommendations made by the Committee on the Elimination of Discrimination against Women. n.d. UN Women. Online: www.un.org/womenwatch/daw/cedaw/recommendations/ recomm.htm (accessed 1 October 2015).

Declaration on the Elimination of Violence against Women, G.A. Res. 48/104, U.N. Doc. A/RES/48/104 (1994). Online: www.un.org/ documents/ga/res/48/a48r104.htm (accessed 30 December 2015).

Office of the United Nations High Commission for Human Rights. Online: www2.ohchr.org/english/bodies/cedaw/sessions.htm (accessed 1 October 2014).

Office of the High Commissioner, Convention on the Rights of the Child, G.A Res. 44/25 (1989). Online: www.ohchr.org/en/ professionalinterest/pages/crc.aspx (accessed 18 April 2016).

Papua New Guinea Responses to the list of issues and questions [from the Committee on the Elimination of Discrimination against Women] with regard to the consideration of the combined initial, second and third periodic reports, CEDAW/C/PNG/Q/3/Add.1 (10 March 2010).

Report of the Committee on the Elimination of Discrimination against Women, General Recommendation No. 19, 11 th Sess., Agenda Item 7, U.N. Doc. CEDAW/C/1992/L.1/Add. 15 (1992).

The Permanent Mission of Papua New Guinea to the United Nations, Delegation to the Forty-sixth Session of the Committee on the Elimination of Discrimination against Women to be Held from 12 to 30 July 2010 (PNG/084/2010).

United Nations Treaty Collection. Online: treaties.un.org/ (accessed 16 November 2016).

Universal Declaration of Human Rights, G.A. Res. 271A(III), U.N. GAOR, 3d Sess., U.N. Doc. A/810 (1948). Online: www.un.org/en/ universal-declaration-human-rights/ (accessed 18 April 2016). 


\section{Cases}

Awop v. Lapemal [2007] VUIC 2. Online: www.paclii.org/vu/cases/ VUIC/2007/2.html (accessed 5 October 2015).

Balelala v. State [2004] FJCA 49. Online: www.paclii.org/fj/cases/ FJCA/2004/49.html (accessed 16 November 2016).

Chittendon v. Knight [1758] 2 Cas. Temp. Lee 559.

Estate of Chinsami Reddy [2000] FJHC 134. Online: www.paclii.org/fj/ cases/FJHC/2000/134.html (accessed 16 November 2016).

Fijian Teachers Association v. President of the Republic of Fiji Islands [2008] JFHC 59. Online: www.paclii.org/cgi-bin/disp.pl/fj/cases/ FJHC/2008/59.html (accessed 5 October 2015).

Hatilia v. Attorney General [2012] SBHC 101. Online: www.paclii.org/ cgi-bin/disp.pl/sb/cases/SBHC/2012/101.html (accessed 5 October 2015).

Joli v. Joli [2003] VUSC 63. Online: www.paclii.org/vu/cases/ VUSC/2003/63.html (accessed 5 October 2015).

Minister of State for Immigration and Ethnic Affairs $v$. Ah Hin Teoh [1995] HCA 20, cited in Prakash v. Narayan [2000] FJHC 145. Online: www.paclii.org/cgi-bin/disp.pl/fj/cases/FJHC/2000/144.html (accessed 5 October 2015).

$N K$ and $Z M R$ [2009] FJHC 95. Online: www.paclii.org/fj/cases/ FJHC/2009/95.html (accessed 16 November 2016).

Police v. Apelu [2010] WSSC 178. Online: www.paclii.org/cgi-bin/disp. pl/ws/cases/WSSC/2010/178.html (accessed 5 October 2015).

Prakash v. Narayan [2000] FJHC 145. Online: www.paclii.org/cgi-bin/ disp.pl/fj/cases/FJHC/2000/144.html (accessed 5 October 2015).

Republic v. Timiti \& Robuti [1998] KIHC 1. Online: www.paclii.org/cgibin/disp.pl/ki/cases/KIHC/1998/35.html (accessed 5 October 2015).

State v. A.V. [2009] FJHC 18. Online: www.paclii.org/cgi-bin/disp.pl/ $\mathrm{fj} /$ cases/FJHC/2009/ (accessed 5 October 2015). 
State v. Basa [2011] FJHC 446. Online: www.paclii.org/cgi-bin/disp. $\mathrm{pl} / \mathrm{fj} /$ cases/FJHC/2011/446.html (accessed 5 October 2015).

State v. Bechu [1999] FJMC 3. Online: www.paclii.org/cgi-bin/disp.pl/ fj/cases/FJHC/1999 (accessed 5 October 2015).

State v. Narakavi [2009] PGNC 109; N 3737. Online: www.paclii.org/ cgi-bin/disp.pl/pg/cases/PGNC/2009/109.html (accessed 5 October 2015).

State v. Patangala [2006] PGNC 43; N3027. Online: www.paclii.org/ cgi-bin/disp.pl/pg/cases/PGNC/2006/43.html (accessed 5 October 2015).

State v. S.N.M. [2011] FJHC 26. Online: www.paclii.org/cgi-bin/disp. pl/fj/cases/FJHC/2011/26.html (accessed 5 October 2015).

Sukuramu v. New Britain Palm Oil Ltd [2007] PGNC 21. Online: www. paclii.org/cgi-bin/disp.pl/pg/cases/PGNC/2007/21.html (accessed 5 October 2015).

Tepulolo v. Pou [2005] TVHC. Online: www.paclii.org/cgi-bin/disp.pl/ tv/cases/TVHC/2005/1.html (accessed 13 September 2016).

Vaai v. Leni [1996] WSCA 8. 
This text is taken from Gender Violence \& Human Rights: Seeking Justice in Fiji, Papua New Guinea and Vanuatu, edited by Aletta Biersack, Margaret Jolly and Martha Macintyre, published 2016 by ANU Press, The Australian National University, Canberra, Australia. 